\title{
Beneficial effects of alpha lipoic acid on cerulein-induced experimental acute pancreatitis in rats
}

\author{
Siçanlarda seruleinle deneysel olarak oluşturulan akut pankreatitte \\ alfa lipoik asitin faydalı etkileri
}

\author{
Nuriye Esen BULUT, ${ }^{1}$ Erkan ÖZKAN, ${ }^{2}$ Osman EKİNCI,${ }^{3}$ Ender DULUNDU, ${ }^{2}$ \\ Ümit TOPALOĞLU, ${ }^{2}$ Ahmet Özer ŞEHİRLİ, ${ }^{4}$ Feriha ERCAN, ${ }^{5}$ Göksel ŞENER ${ }^{4}$
}

\section{BACKGROUND}

The present study aimed to determine the effects of alpha lipoic acid (ALA) on blood and tissue biochemical parameters, as well as tissue histopathology, in an experimental rat model of cerulein-induced acute pancreatitis (AP).

\section{METHODS}

Three groups consisting of eight rats each were used, as follows: Group 1, controls; Group 2, cerulein-induced pancreatitis group treated with saline; and Group 3, ceruleininduced pancreatitis group treated with ALA. AP was induced by intraperitoneal administration of cerulein $(20 \mu \mathrm{g} /$ $\mathrm{kg}) 4$ times at 1-hour intervals. The animals were decapitated 12 hours after the last dose of cerulein. Blood amylase, lipase, interleukin (IL)-1ß, and tumor necrosis factor (TNF)- $\alpha$ levels, pancreas tissue glutathione (GSH) and malondialdehyde (MDA) levels, as well as myeloperoxidase (MPO) and $\mathrm{Na}^{+}-\mathrm{K}^{+}$-ATPase activity were measured. Pancreatic tissue samples were also evaluated histopathologically under a light microscope.

\section{RESULTS}

While plasma amylase, lipase, IL-1 1 , and TNF- $\alpha$ levels, and tissue MDA and MPO levels significantly increased in rats with cerulean-induced AP, tissue GSH and $\mathrm{Na}+-\mathrm{K}+-$ ATPase activity significantly reduced. These changes were reversed and improved with ALA treatment.

\section{CONCLUSION}

Our findings suggest that ALA may significantly reduce morbidity and mortality by preventing organ dysfunction induced by free radicals in the pancreas.

Key Words: Acute pancreatitis; alpha lipoic acid; cerulein; cytokines; free oxygen radicals.

\section{AMAÇ}

Bu çalışmada, sıçanlarda seruleinle deneysel olarak oluşturulan akut pankreatit (AP) modelinde alfa lipoik asitin (ALA) kan biyokimyasal parametreleri ve doku düzeyindeki etkileri araştırıldı.

\section{GEREÇ VE YÖNTEM}

Her biri 8 siçandan oluşan 3 grup oluşturuldu. Grup 1: Kontrol; Grup 2: Seruleinle pankreatit oluşturulup salin verilen grup; Grup 3: Seruleinle pankreatit oluşturulup ALA verilen grup. AP intraperitoneal olarak $20 \mu \mathrm{g} / \mathrm{kg}$ dozunda seruleinin 1'er saat aralıklarla 4 defa verilmesiyle oluşturuldu. Son serulein dozundan 12 saat sonra hayvanlar dekapite edildi. Kan amilaz, lipaz, interlökin (IL)-1ß, tümör nekroz faktör (TNF)-alfa düzeyleri, pankreas doku glutatyon (GSH), malondialdehid (MDA), miyeloperoksidaz (MPO) ve $\mathrm{Na}^{+}-\mathrm{K}^{+}-$ ATPase aktivitesi belirlendi. Ayrıca pankreas doku örnekleri histopatolojik olarak mikroskopta değerlendirildi.

\section{BULGULAR}

Seruleinle pankreatit oluşturulan grupta kan amilaz, lipaz, IL-1ß, TNF-alfa düzeyleri, doku MDA, MPO düzeyleri anlamlı derecede artarken, doku GSH ve $\mathrm{Na}^{+}-\mathrm{K}^{+}$-ATPase aktivitesi anlamlı derecede azaldı. ALA tedavisiyle bu değerlerde ve histopatolojide tersine değişiklikler, düzelme ve iyileşme görüldü.

\section{SONUÇ}

Mevcut bulgular ALA tedavisinin, pankreasta oluşabilecek serbest radikallerin neden olduğu organ ve fonksiyon bozukluğunu önleyerek morbidite ve mortaliteyi önemli oranda azaltabileceğini düşündürmektedir.

Anahtar Sözcükler: Akut pankreatit; alfa lipoik asit; serulein; sitokinler; serbest oksijen radikalleri.

\footnotetext{
${ }^{1}$ Department of General Surgery, Fatih Sultan Mehmet Training and Research Hospital, Istanbul; Departments of ${ }^{2} 5$ th General Surgery,

${ }^{3}$ Anesthesiology and Reanimation, Haydarpasa Numune Training and Research Hospital, Istanbul; ${ }^{4}$ Department of Pharmacology, Marmara University, Faculty of Pharmacy, Istanbul; ${ }^{5}$ Department of Histology and Embryology, Marmara University, Faculty of Medicine, Istanbul, Turkey.
}

\footnotetext{
${ }^{1}$ Fatih Sultan Mehmet Eğitim ve Araştırma Hastanesi, Genel Cerrahi Kliniği, İstanbul; Haydarpaşa Numune Eğitim ve Araștırma Hastanesi, ${ }^{2}$ 5. Genel Cerrahi Kliniği, ${ }^{3}$ Anesteziyoloji ve Reanimasyon Kliniği, İstanbul; ${ }^{4}$ Marmara Üniversitesi Eczacılık Fakültesi, Farmakoloji Anabilim Dalı, İstanbul; ${ }^{5}$ Marmara Üniversitesi Tıp Fakültesi, Histoloji ve Embriyoloji Anabilim Dalı, İstanbul.
} 
Acute pancreatitis (AP) is an inflammatory disease of the pancreas that is associated with little or no fibrosis of the gland. ${ }^{[1]}$ The experimental and clinical pathophysiology of AP is poorly understood. Therefore, AP continues to be associated with significant mortality and morbidity. ${ }^{[2]}$ It has recently been demonstrated that excessive formation of free oxygen radicals and changes in cytokine levels might have a role in the pathogenesis of AP. Free oxygen radicals may contribute to pancreatic acinar cell damage due to ischemia reperfusion injury through consumption of antioxidants within the tissue, and also have direct toxic effects on acinar cells. ${ }^{[3,4]}$ Several cytokines are released from damaged pancreatic cells and systemic immune cells during pancreatic inflammation. Interleukin (IL)1 and tumor necrosis factor (TNF)- $\alpha$ are major cytokines that play a role in AP. In addition, IL-2, IL-6, IL-8, IL-10, and nitric oxide (NO) contribute to deterioration in the clinical condition. These cytokines lead to worsening of AP and systemic complications by increasing capillary permeability. ${ }^{[5]}$ Alpha lipoic acid (ALA) is a strong antioxidant with anti-inflammatory effects. ${ }^{[6,7]}$ In several studies, ALA has been demonstrated to inhibit free radicals that cause oxidative damage. ${ }^{[8,9]}$ Cerulein is widely used in experimental models of AP. ${ }^{[10,11]}$ Intraperitoneal, intravenous and subcutaneous administration of cerulein leads to edematous pancreatitis and necrotizing pancreatitis, which are characterized by edema and increased levels of serum amylase, as well as by acinar cell vacuolization and leukocyte infiltration histologically, through the stimulation of cholecystokinin receptors within the pancreatic tissue. ${ }^{[12,13]}$

The aim of the present study was to determine the effects of ALA, which has anti-oxidative and antiinflammatory properties, on blood and tissue biochemical parameters as well as tissue histopathology in an experimental rat model of cerulein-induced AP.

\section{MATERIALS AND METHODS}

\section{Animals}

Sprague-Dawley rats of either sex (200-250 g) were maintained in a room at a constant temperature of $22 \pm 1{ }^{\circ} \mathrm{C}$ with 12-hour (h) light/dark cycles and fed standard pellet chow and water ad libitum. This study was approved by the Animal Ethics Committee regulations after obtaining approval from the Animal Experimentation Ethics Committee of Haydarpasa Numune Training and Research Hospital, Experimental Research Animal Laboratory.

\section{Experimental Protocol}

Three groups consisting of eight animals each were used. AP was induced by intraperitoneal administration of cerulein $(20 \mu \mathrm{g} / \mathrm{kg}$; Sigma, St. Louis, MO, USA) 4 times at 1 -h intervals. Group 1 consisted of control animals. Group 2 was the cerulein-induced pancreatitis group treated with intraperitoneal isotonic sodium chloride infusion $6 \mathrm{~h}$ after the last dose of cerulein. Group 3 was the cerulein-induced pancreatitis group treated with $100 \mathrm{mg} / \mathrm{kg}$ intraperitoneal ALA $6 \mathrm{~h}$ after the last dose of cerulein; this dose of ALA was previously shown to be an effective anti-inflammatory dose. ${ }^{[14,15]}$ The animals were decapitated $12 \mathrm{~h}$ after the last dose of cerulein.

Trunk blood was collected for the assessment of amylase, lipase, TNF- $\alpha$, and IL- $1 \beta$. To evaluate the presence of oxidative damage in the pancreas, tissue samples were obtained and stored at $-80^{\circ} \mathrm{C}$ for the determination of malondialdehyde (MDA) and glutathione (GSH) levels and myeloperoxidase (MPO) and $\mathrm{Na}^{+}-\mathrm{K}^{+}$-ATPase activities. For histological analysis, tissue samples were fixed in $10 \%(\mathrm{v} / \mathrm{v})$ buffered formaldehyde, and processed for routine paraffin embedding. Tissue sections $(6 \mu \mathrm{m})$ were stained with hematoxylin and eosin (H\&E), and examined under a light microscope (Olympus-BH-2). Histological assessments were performed by an experienced histologist who was blinded to the treatment conditions.

\section{Biochemical Analysis}

Plasma amylase and lipase levels were determined spectrophotometrically using an automated analyzer (Olympus AU 600; Diamond Diagnostics, Holliston, MA, USA), whereas TNF- $\alpha$ and IL- $1 \beta$ were quantified in accordance with the manufacturer's instructions and guidelines using enzyme-linked immunosorbent assay (ELISA) kits (Biosource International, Nivelles, Belgium). These particular assay kits were selected because of their high degree of sensitivity, specificity, inter- and intra-assay precision, and the small amount of plasma sample required to conduct the assay.

\section{Measurement of Pancreatic Malondialdehyde and Glutathione Levels}

Tissue samples were homogenized with ice-cold $150 \mathrm{mM} \mathrm{KCl}$ for the determination of MDA and GSH levels. The MDA levels were assayed for the products of lipid peroxidation by monitoring the formation of thiobarbituric acid reactive substances, as described previously. ${ }^{[16]}$ Lipid peroxidation was expressed in terms of MDA equivalents using an extinction coefficient of $1.56 \times 10^{5} \mathrm{M}^{-1} \mathrm{~cm}^{-1}$, and the results were expressed as nmol MDA/g tissue. GSH measurements were performed using a modification of the Ellman procedure. ${ }^{[17]}$ Briefly, after centrifugation at $1200 \mathrm{xg}$ for $10 \mathrm{mi}-$ nutes (min), $0.5 \mathrm{ml}$ of supernatant was added to $2 \mathrm{ml}$ of $0.3 \mathrm{~mol} / \mathrm{L} \mathrm{Na} \mathrm{HPO}_{4} \cdot 2 \mathrm{H}_{2} \mathrm{O}$ solution. A $0.2 \mathrm{ml}$ solution of dithiobisnitrobenzoate $(0.4 \mathrm{mg} / \mathrm{ml} 1 \%$ sodium citrate) was added, and the absorbance at $412 \mathrm{~nm}$ was measured immediately after mixing. GSH levels were calculated using an extinction coefficient of $1.36 \times 10^{4} \mathrm{M}^{-1}$ $\mathrm{cm}^{-1}$. Results were expressed as $\mu \mathrm{mol} \mathrm{GSH} / \mathrm{g}$ tissue. 


\section{Measurement of Pancreatic Myeloperoxidase Activity}

Myeloperoxidase (MPO) is an enzyme that is found predominantly in the azurophilic granules of polymorphonuclear leukocytes (PMN). Tissue MPO activity is frequently utilized to estimate tissue PMN accumulation in inflamed tissues and correlates significantly with the number of PMN determined histochemically in tissues. ${ }^{[18]}$ MPO activity was measured in tissues in a procedure similar to that documented by Hillegass et al. ${ }^{[19]}$ Tissue samples were homogenized in $50 \mathrm{mM}$ potassium phosphate buffer ( $\mathrm{PB}, \mathrm{pH} 6.0)$, and centrifuged at 41,400 xg for $10 \mathrm{~min}$. The pellets were suspended in $50 \mathrm{mM}$ PB containing $0.5 \%$ hexadecyltrimethylammonium bromide. After three freeze and thaw cycles with sonication between the cycles, the samples were centrifuged at $41,400 \mathrm{xg}$ for $10 \mathrm{~min}$. Aliquots $(0.3 \mathrm{ml})$ were added to $2.3 \mathrm{ml}$ of reaction mixture containing $50 \mathrm{mM} \mathrm{PB}$, o-dianisidine and 20 $\mathrm{mM} \mathrm{H} \mathrm{O}_{2}$ solution. One unit of enzyme activity was defined as the amount of MPO that caused a change in absorbance measured at $460 \mathrm{~nm}$ for $3 \mathrm{~min}$. MPO activity was expressed as $\mathrm{U} / \mathrm{g}$ tissue.

\section{Measurement of $\mathrm{Na}^{+}-\mathrm{K}^{+}$-ATPase Activity}

Measurement of $\mathrm{Na}^{+}-\mathrm{K}^{+}$-ATPase activity is based on the measurement of inorganic phosphate that is formed from $3 \mathrm{mM}$ disodium adenosine triphosphate added to the medium during the incubation period..$^{[20]}$ The medium was incubated in a $37^{\circ} \mathrm{C}$ water bath for $5 \mathrm{~min}$ with a mixture of $100 \mathrm{mM} \mathrm{NaCl}, 5 \mathrm{mM} \mathrm{KCl}, 6$ $\mathrm{mM} \mathrm{MgCl}, 0.1 \mathrm{mM}$ EDTA, and $30 \mathrm{mM}$ Tris $\mathrm{HCl}(\mathrm{pH}$ 7.4). Following the pre-incubation period, $\mathrm{Na}_{2} \mathrm{ATP}$, at a final concentration of $3 \mathrm{mM}$, was added to each tube, and the tubes were incubated at $37^{\circ} \mathrm{C}$ for $30 \mathrm{~min}$. After the incubation, the tubes were placed in an ice bath, and the reaction was terminated. Subsequently, the level of inorganic phosphate was determined using a spectrophotometer (Shimadzu, Japan) at an excitation wavelength of $690 \mathrm{~nm}$. The specific activity of the enzyme was expressed as $\mathrm{Pi} \mathrm{mg}^{-1}$ protein $\mathrm{h}^{-1}$. The protein concentration of the supernatant was measured by the Lowry method. ${ }^{[21]}$

\section{Histopathologic Evaluation of Pancreatic Damage}

For light microscopic analysis, samples from the pancreas were fixed in 10\% buffered formalin for 48 hours, dehydrated in an ascending alcohol series, and embedded in paraffin wax. Sections, approximately 5 $\mu \mathrm{m}$ in thickness, were stained with H\&E for general morphology. Histological assessments were performed with a photomicroscope (Olympus BX 51; Tokyo, Japan) by an experienced histologist who was blinded to the experimental groups.

\section{Statistical Analysis}

Statistical analysis was carried out using GraphPad Prism 3.0 (GraphPad Software, San Diego, CA, USA). All data are expressed as the mean \pm standard error of the mean (SEM). Groups of data were compared with an analysis of variance (ANOVA), followed by Tukey's multiple comparison tests. A p value $<0.05$ was accepted as statistically significant.

\section{RESULTS}

Plasma amylase and lipase levels were significantly higher in the saline-treated pancreatitis group compared to the control group $(\mathrm{p}<0.01)$. Amylase and lipase levels were significantly lower in the ALA-treated pancreatitis group compared to the saline-treated pancreatitis group $(p<0.01$ and $p<0.001$, respectively; Table 1, Fig. 1a, 1b).

Tumor necrosis factor (TNF)- $\alpha$ and IL- $1 \beta$ levels were significantly higher in the saline-treated pancreatitis group compared to the control group, clearly indicating that inflammatory reactions increased within the tissue $(p<0.001)$. The levels of these cytokines were significantly lower in the ALA-treated pancreatitis group compared to the saline-treated pancreatitis group ( $<<0.01$; Table 1, Fig. 2a, 2b).

Glutathione (GSH) is an important antioxidant that is protective against free oxygen radicals formed in several tissues as a result of pancreatitis. The level of reduced GSH in the saline-treated pancreatitis group was significantly lower compared to the control group

Table 1. Plasma amylase, lipase, tumor necrosis factor- $\alpha$, and interleukin- $1 \beta$ levels in the sham-operated control or cerulein-induced acute pancreatitis groups treated with either saline or alpha lipoic acid

\begin{tabular}{lccc}
\hline & & \multicolumn{2}{c}{ Cerulein-induced pancreatitis groups } \\
\cline { 3 - 3 } & Controls $(\mathrm{n}=8)$ & $\begin{array}{c}\text { Saline-treated }(\mathrm{n}=8) \\
\text { Mean } \pm \text { SEM }\end{array}$ & $\begin{array}{c}\text { ALA-treated }(\mathrm{n}=8) \\
\text { Mean } \pm \text { SEM }\end{array}$ \\
\hline Amylase (U/L) & $594 \pm 67.00$ & $1182 \pm 81^{* *}$ & $818 \pm 48^{++}$ \\
Lipase (U/L) & $65.13 \pm 10.02$ & $345 \pm 24.5^{* *}$ & $93.13 \pm 14.41^{+++}$ \\
TNF- $\alpha(\mathrm{pg} / \mathrm{ml})$ & $6.35 \pm 0.96$ & $45.23 \pm 8.22^{* * *}$ & $15.95 \pm 2.66^{++}$ \\
IL-1 $\beta(\mathrm{pg} / \mathrm{ml})$ & $10.88 \pm 1.71$ & $55.47 \pm 6.24^{* * *}$ & $21.35 \pm 4.29^{+++}$ \\
\hline
\end{tabular}

ALA: Alpha lipoic acid; TNF- $\alpha$ : Tumor necrosis factor- $\alpha$; IL-1 $\beta$ : Interleukin- $1 \beta$; SEM: Standard error of the mean.

$* * \mathrm{p}<0.01, * * * \mathrm{p}<0.001$ compared to controls; $++\mathrm{p}<0.01,+++\mathrm{p}<0.001$ compared to saline-treated group. 
Table 2. Tissue glutathione and malondialdehyde levels and myeloperoxidase and $\mathrm{Na}+-\mathrm{K}+$-ATPase activities in the sham-operated control or cerulein-induced acute pancreatitis groups treated with either saline or ALA

\begin{tabular}{|c|c|c|c|}
\hline & \multirow[b]{2}{*}{$\begin{array}{c}\text { Controls }(\mathrm{n}=8) \\
\text { Mean } \pm \text { SEM }\end{array}$} & \multicolumn{2}{|c|}{ Cerulein-induced pancreatitis groups } \\
\hline & & $\begin{array}{c}\text { Saline-treated }(\mathrm{n}=8) \\
\text { Mean } \pm \text { SEM }\end{array}$ & $\begin{array}{c}\text { ALA-treated }(\mathrm{n}=8) \\
\text { Mean } \pm \text { SEM }\end{array}$ \\
\hline GSH (mmol/g) & $2.29 \pm 0.15$ & $0.97 \pm 0.18^{* * *}$ & $2.19 \pm 0.11^{+++}$ \\
\hline MDA (nmol/g) & $28.67 \pm 4.21$ & $59.68 \pm 6.48^{* *}$ & $30.10 \pm 3.85^{++}$ \\
\hline MPO (U/g) & $9.83 \pm 1.48$ & $28.44 \pm 4.37^{* *}$ & $13.66 \pm 2.43^{++}$ \\
\hline $\begin{array}{l}\mathrm{Na}^{+}-\mathrm{K}^{+} \text {-ATPase } \\
(\mathrm{mmol} / \mathrm{mg} \text { protein/h) }\end{array}$ & $2.44 \pm 0.32$ & $1.14 \pm 0.20^{* *}$ & $2.38 \pm 0.15^{++}$ \\
\hline
\end{tabular}

ALA: Alpha lipoic acid; GSH: Glutathione; MDA: Malondialdehyde; MPO: Myeloperoxidase; SEM: Standard error of the mean. $* * \mathrm{p}<0.01,{ }^{* * *} \mathrm{p}<0.001$ compared to controls; $++\mathrm{p}<0.01,+++\mathrm{p}<0.001$ compared to saline-treated group.

$(p<0.001)$. The level of reduced GSH was significantly higher in the ALA-treated pancreatitis group compared to the saline-treated group $(\mathrm{p}<0.001$; Table 2, Fig. 3a).

In order to assess pancreatic damage, levels of MDA, an end-product of lipid peroxidation, were measured as an indicator of oxidative injury. MDA levels in the saline-treated pancreatitis group were significantly higher compared to the control group $(\mathrm{p}<0.01)$. MDA levels were significantly lower in the ALA- treated pancreatitis group than the saline-treated group ( $<<0.01$; Table 2, Fig. 3b).

Myeloperoxidase (MPO) activity was measured in tissue samples as an indicator of neutrophilic infiltration. MPO activity significantly increased in the saline-treated pancreatitis group compared to the control group $(\mathrm{p}<0.01)$, whereas the MPO activity was significantly lower in the ALA-treated pancreatitis group than the saline-treated group ( $\mathrm{p}<0.01$; Table 2, Fig. 4a).

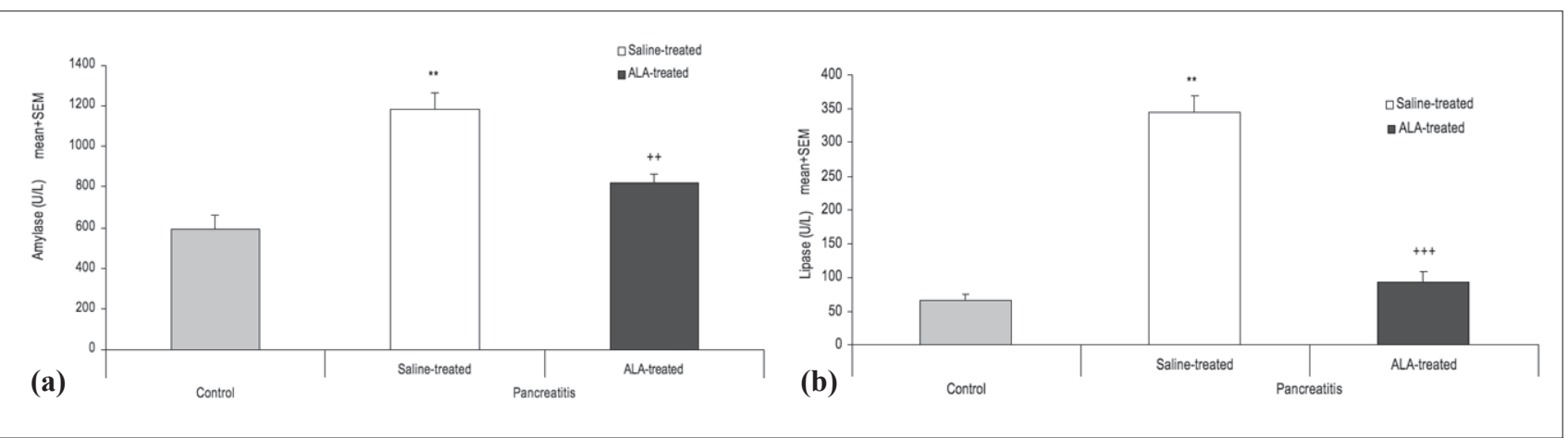

Fig. 1. Plasma amylase and lipase levels in the sham-operated control or cerulein-induced acute pancreatitis groups treated with either saline or alpha lipoic acid (ALA). ${ }^{* *} \mathrm{p}<0.01, * * * \mathrm{p}<0.001$ compared to controls; $++\mathrm{p}<0.01,+++\mathrm{p}<0.001$ compared to saline-treated group.

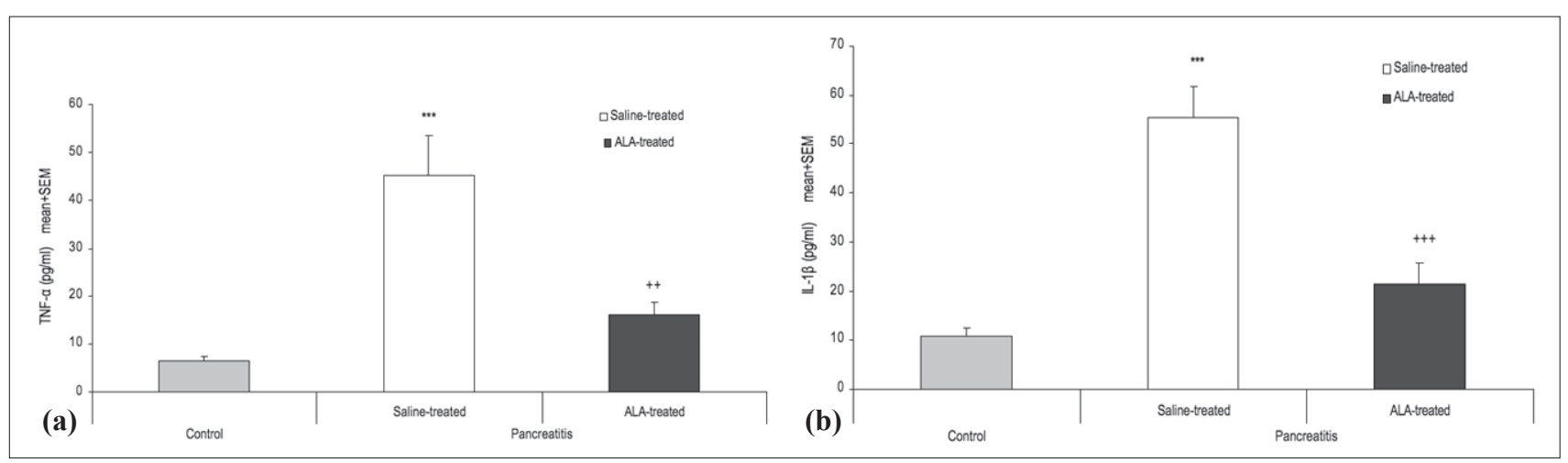

Fig. 2. Serum tumor necrosis factor (TNF)- $\alpha$ and interleukin (IL)-1 $\beta$ levels in the sham-operated control or cerulein-induced acute pancreatitis groups treated with either saline or alpha lipoic acid (ALA). ** $\mathrm{p}<0.01, * * * \mathrm{p}<0.001$ compared to controls; $++\mathrm{p}<0.01,+++\mathrm{p}<0.001$ compared to saline-treated group. 


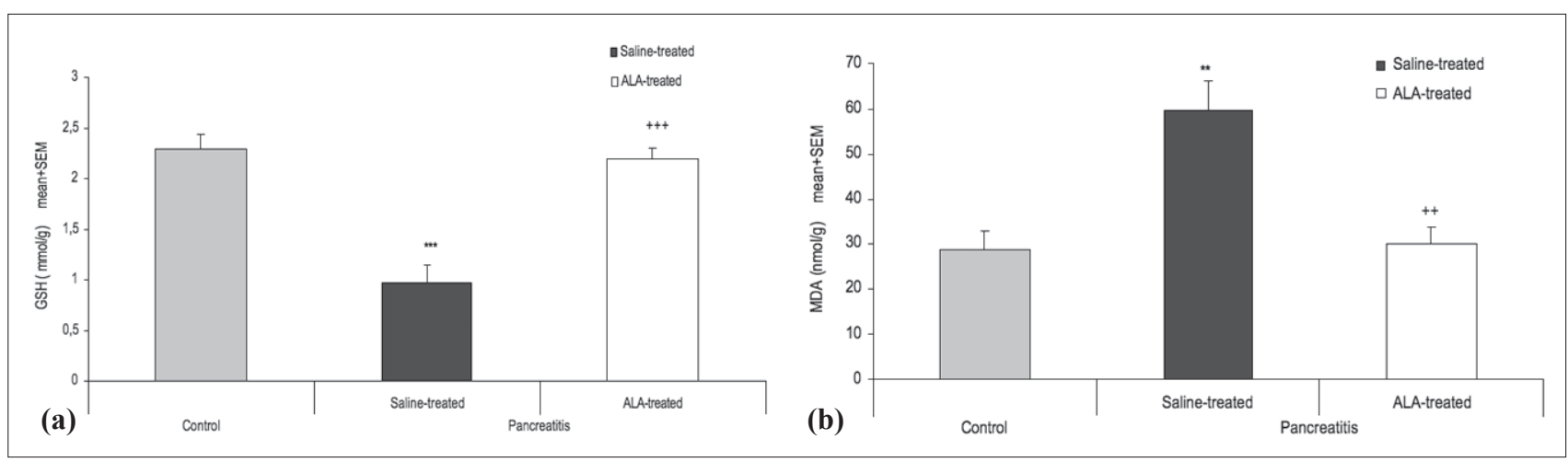

Fig. 3. Tissue glutathione (GSH) and malondialdehyde (MDA) levels in the sham-operated control or cerulein-induced acute pancreatitis groups treated with either saline or alpha lipoic acid (ALA). $* * \mathrm{p}<0.01, * * * \mathrm{p}<0.001$ compared to controls; $++\mathrm{p}<0.01,+++\mathrm{p}<0.001$ compared to saline-treated group.

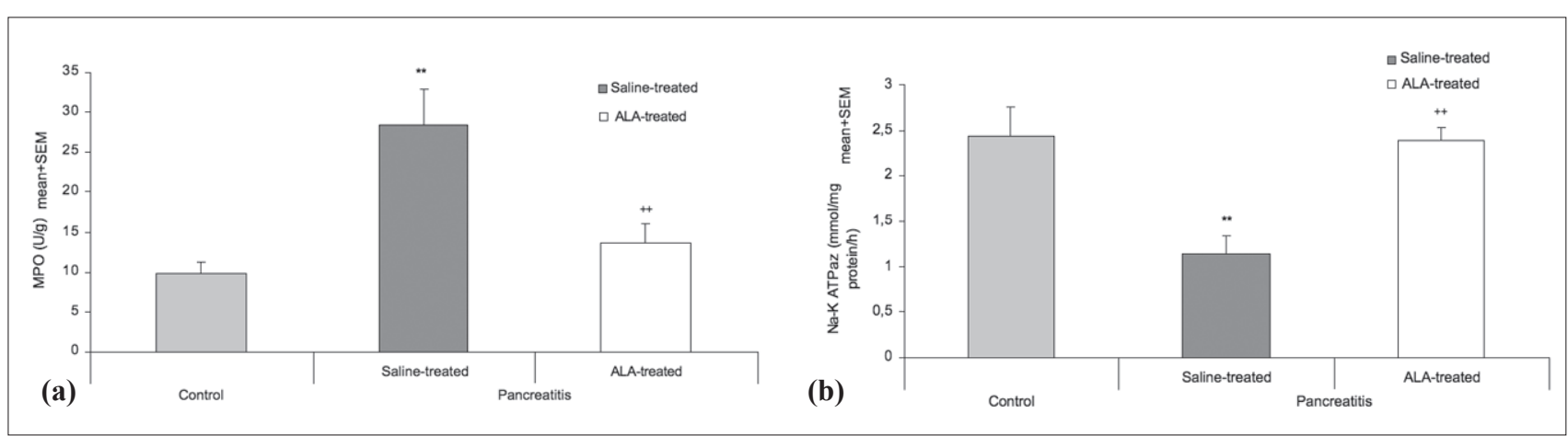

Fig. 4. Tissue myeloperoxidase and $\mathrm{Na}^{+}-\mathrm{K}^{+}$-ATPase activities in the sham-operated control or cerulein-induced acute pancreatitis groups treated with either saline or alpha lipoic acid (ALA). $* * p<0.01$ compared to controls; $++p<0.01$ compared to saline-treated group.

Free oxygen radical formation leads to lipid peroxidation, which results in dysfunction in the erythrocyte membrane system and loss of activity in the membrane-enzyme systems, and thereby inactivation of $\mathrm{Na}^{+}-\mathrm{K}^{+}$-ATPase. In the present study, the $\mathrm{Na}^{+}-\mathrm{K}^{+}$-ATPase level was significantly lower in the saline-treated pancreatitis group than the control group $(\mathrm{p}<0.01)$, whereas it was significantly higher in the ALA-treated pancreatitis group than the saline-treated pancreatitis group $(\mathrm{p}<0.01$; Table 2, Fig. $4 b)$.

\section{Histologic Preparation and Analysis}

Histopathologic scoring included assessment of edema, acinar necrosis, inflammatory cell infiltration, and hemorrhage. While regular pancreas morphology was observed in the control group, varying degrees of acinar swelling, pancreatic tissue necrosis, hemorrhage, and inflammatory cell infiltration were observed in the pancreatitis group. Histopathologic changes in the pancreas were moderately improved in the ALA-treated pancreatitis group (Fig. 5).
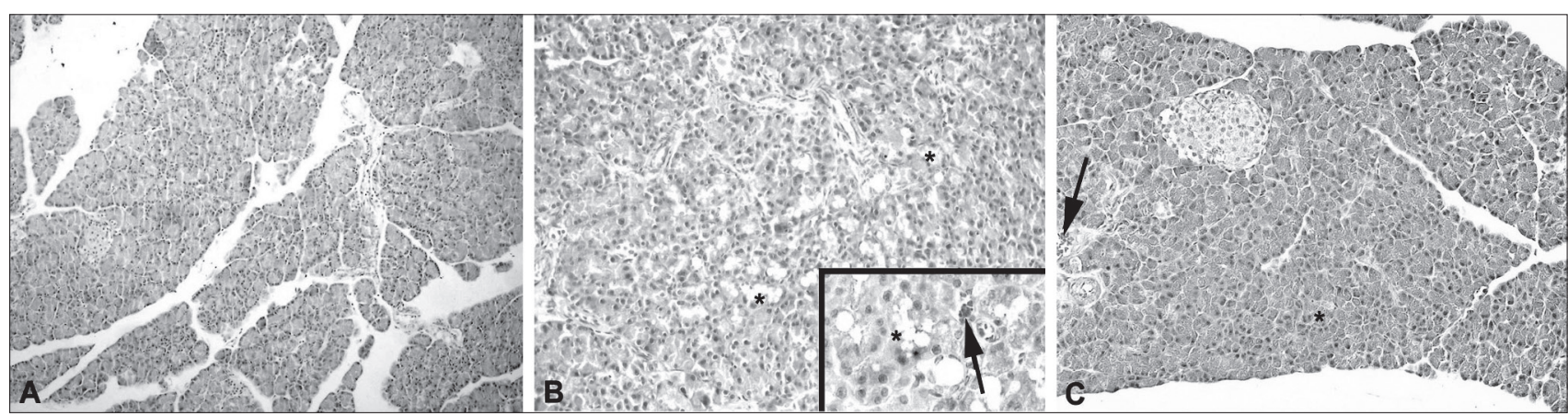

Fig. 5. Histopathological assessment (Hematoxylin and eosin staining, original magnification X200). (A) Control group, normal pancreatic appearance; (B) Saline-treated pancreatitis group, acinar necrosis (*) and vascular congestion (arrow) are noted; and (C) ALA-treated pancreatitis group, mild acinar necrosis (*) and vascular congestion (arrow). 


\section{DISCUSSION}

Acute pancreatitis (AP) is a local or systemic inflammatory condition affecting surrounding tissues and organs to various degrees together with the pancreas. Several clinical forms exist, varying from edematous pancreatitis with low mortality to hemorrhagic or severe AP with high mortality. ${ }^{[22]}$ Administration of cerulein in various doses and routes leads to various degrees of AP in rats. ${ }^{[23]}$ The intraperitoneal administration of cerulein at a dose of $20 \mu \mathrm{g} / \mathrm{kg}, 2-4$ times at 1-h intervals, leads to acute edematous pancreatitis, whereas the intraperitoneal administration of cerulein at a dose of $40-50 \mu \mathrm{g} / \mathrm{kg}, 2-4$ times at 1-hour intervals, causes acute hemorrhagic necrotizing pancreatitis. Macroscopically, in rats treated with cerulein, the pancreas is enlarged and becomes edematous. The earliest histologic changes after subcutaneous and intraperitoneal cerulein administration occur in cytoplasmic vacuoles, and these vacuoles reach enormous sizes with the progression of pancreatitis. Significant interstitial inflammation and acinar cell necrosis occur within 6 hours following the administration of cerulein, reach a maximum level by the 12th hour, and often disappear within 4 days. Studies have shown that the major effect of ALA is its anti-inflammatory effect on collagen tissue and the nervous system. Another effect is protection of vessels against oxidative injury. ${ }^{[24]}$ Several other pharmacologic and therapeutic effects of ALA include vasodilator, anti-carcinogenic, anti-allergic, anti-inflammatory, anti-fungal, anti-arthritic, anti-bacterial, cardioprotective, immunostimulant, and anti-viral effects. ${ }^{[25,26]}$

Amylase and lipase levels are the most common parameters used for the diagnosis of AP. Amylase and lipase levels often elevate in case of AP, but not in parallel with the severity of pancreatitis. ${ }^{[27]}$ In the present study, amylase and lipase levels were significantly lower in the ALA-treated cerulein-induced AP group than the saline-treated group $(p<0.01$ and $p<0.001$, respectively).

Tumor necrosis factor (TNF)- $\alpha$ and IL- $1 \beta$ are the major cytokines released from macrophages. In addition to their cytotoxic effects, they also play a significant role in inflammatory reactions and regulation of inflammation. ${ }^{[28]}$ Neutrophils release free oxygen radicals and several lysosomal enzymes during inflammation and following trauma. TNF- $\alpha$ and IL- $1 \beta$ are also released from activated neutrophils following stimulation. ${ }^{[29,30]}$ In our study, the TNF- $\alpha$ and IL- $1 \beta$ levels were lower in the ALA-treated pancreatitis group than the saline-treated group $(\mathrm{p}<0.01)$. These results suggest that ALA decreases the inflammatory response by inhibiting activation and infiltration of neutrophils, which play a role in triggering tissue damage, and that ALA protects the pancreas tissue from free oxygen radical-induced damage.
Lipids are one of the major targets for free radical damage following pancreatitis. Free oxygen radicals initiate lipid peroxidation by removing one hydrogen atom from polyunsaturated fatty acids with the subsequent formation of hydroperoxides. As a result of these reactions, the membrane fluidity and membrane integrity of cells are impaired, leading to disintegration of cells and cell death. These subcellular structures that are released into the extracellular environment trigger several inflammatory events and further worsen the ongoing damage. ${ }^{[31]}$ The MDA level was measured as an indicator of lipid peroxidation in the current study. The MDA level in the ALA-treated pancreatitis group was found to be significantly lower compared to the saline-treated group $(\mathrm{p}<0.01)$. MPO is an essential enzyme for normal neutrophil function and is used as an index of tissue neutrophil infiltration because its levels increase when neutrophils are stimulated by various stimulants. ${ }^{[32,33]}$ We observed that ALA administration reduced the MPO levels, suggesting a protective effect against free oxygen radical-induced damage through inhibition of neutrophil infiltration and activation in the pancreatic tissues.

All aerobic organisms are exposed to oxidative stress physiologically during their metabolism. GSH protects the cell from oxidative injury by reacting with free radicals and peroxides. It has been shown in several studies that tissue GSH levels are rapidly decreased during pancreatic damage. ${ }^{[34]}$ In our study, the GSH level was significantly higher in the ALA-treated pancreatitis group than the saline-treated group $(p<0.001)$.

Lipid peroxidation occurs due to the formation of free oxygen radicals, which in turn leads to dysfunction in the erythrocyte membrane system and loss of activity in the membrane-enzyme systems. Consequently, $\mathrm{Na}^{+}-\mathrm{K}^{+}$-ATPase is inactivated. As in other transport enzymes within the erythrocyte membrane, $\mathrm{Na}^{+}-$ $\mathrm{K}^{+}$-ATPase enzyme is also known to depend on the presence of membrane phospholipids for its activation. ${ }^{[35,36]}$ We found that the $\mathrm{Na}^{+}-\mathrm{K}^{+}$-ATPase activity level was significantly higher in the ALA-treated pancreatitis group compared to the saline-treated group $(\mathrm{p}<0.01)$.

Although pancreatic tissue damage can be assessed by various parameters, we used serum TNF- $\alpha$ and IL-1 $\beta$ levels, tissue GSH and MDA levels and MPO and $\mathrm{Na}^{+}-\mathrm{K}^{+}$-ATPase activity in the current study. In the present study, while amylase, lipase, TNF- $\alpha$, IL$1 \beta$, MDA, and MPO were found to be significantly lower in the ALA-treated pancreatitis group compared to the saline-treated pancreatitis group, $\mathrm{GSH}$ and $\mathrm{Na}^{+}-$ $\mathrm{K}^{+}$-ATPase levels were significantly higher. In conclusion, our findings suggest that ALA may significantly reduce morbidity and mortality by preventing organ dysfunction induced by free radicals in the pancreas. 


\section{REFERENCES}

1. Fisher WE, Andersen DK, Bell RH Jr, Saluja AK, Brunicardi FC. Schwartz's principles of surgery. Pancreas. Chapter 33, 9th ed., 2010. p. 1177-86.

2. Bülbüller N, Doğru O, Umaç H, Gürsu F, Akpolat N. The effects of melatonin and pentoxiphylline on L-arginine induced acute pancreatitis. Ulus Travma Acil Cerrahi Derg 2005;11:108-14.

3. Zeybek N, Gorgulu S, Yagci G, Serdar M, Simsek A, Kaymakcioglu N, et al. The effects of gingko biloba extract (EGb 761) on experimental acute pancreatitis. J Surg Res 2003;115:286-93.

4. Pooran N, Indaram A, Singh P, Bank S. Cytokines (IL-6, IL8 , TNF): early and reliable predictors of severe acute pancreatitis. J Clin Gastroenterol 2003;37:263-6.

5. Gukovsky I, Gukovskaya AS, Blinman TA, Zaninovic V, Pandol SJ. Early NF-kappaB activation is associated with hormone-induced pancreatitis. Am J Physiol 1998;275:G140214.

6. Park KG, Kim MJ, Kim HS, Lee SJ, Song DK, Lee IK. Prevention and treatment of macroangiopathy: focusing on oxidative stress. Diabetes Res Clin Pract 2004;66:57-62.

7. Atmaca G. Antioxidant effects of sulfur-containing amino acids. Yonsei Med J 2004;45:776-88.

8. Park SJ, Seo SW, Choi OS, Park CS. Alpha-lipoic acid protects against cholecystokinin-induced acute pancreatitis in rats. World J Gastroenterol 2005; 11:4883-5.

9. Ghibu S, Richard C, Vergely C, Zeller M, Cottin Y, Rochette L. Antioxidant properties of an endogenous thiol: Alpha-lipoic acid, useful in the prevention of cardiovascular diseases. J Cardiovasc Pharmacol 2009;54:391-8.

10. Yonetci N, Sungurtekin U, Oruc N, Yilmaz M, Sungurtekin $\mathrm{H}$, Kaleli I, et al. Is procalcitonin a reliable marker for the diagnosis of infected pancreatic necrosis? ANZ J Surg 2004; 74:591-5.

11. Um SH, Kwon YD, Kim CD, Lee HS, Jeen YT, Chun HJ, et al. The role of nitric oxide in experimental cerulein induced pancreatitis. J Korean Med Sci 2003;18:520-6.

12. Ozturk F, Gul M, Esrefoglu M, Ates B. The contradictory effects of nitric oxide in caerulein-induced acute pancreatitis in rats. Free Radic Res 2008;42:289-96.

13. Ding SP, Li JC, Jin C. A mouse model of severe acute pancreatitis induced with caerulein and lipopolysaccharide. World $\mathbf{J}$ Gastroenterol 2003;9:584-9.

14. Dulundu E, Ozel Y, Topaloglu U, Sehirli O, Ercan F, Gedik $\mathrm{N}$, et al. Alpha-lipoic acid protects against hepatic ischemiareperfusion injury in rats. Pharmacology 2007;79:163-70.

15. Sehirli O, Sener E, Cetinel S, Yüksel M, Gedik N, Sener G. Alpha-lipoic acid protects against renal ischaemia-reperfusion injury in rats. Clin Exp Pharmacol Physiol 2008;35:24955 .

16. Buege JA, Aust SD. Microsomal lipid peroxidation. Methods Enzymol 1978;52:302-10.

17. Beutler E. Glutathione in red blood cell metabolism. A manual of biochemical methods. New York: Grune\&Stratton; 1975. p. 112-114.

18. Bradley PP, Priebat DA, Christensen RD, Rothstein G. Measurement of cutaneous inflammation: estimation of neutrophil content with an enzyme marker. J Invest Dermatol 1982;78:206-9.

19. Hillegass LM, Griswold DE, Brickson B, Albrightson-Winslow C. Assessment of myeloperoxidase activity in whole rat kidney. J Pharmacol Methods 1990;24:285-95.
20. Reading HW, Isbir T. The role of cation-activated ATPases in transmitter release from the rat iris. Q J Exp Physiol Cogn Med Sci 1980;65:105-16.

21.Lowry OH, Rosebrough NJ, Farr AL, Randall RJ.. Protein measurement with the Folin phenol reagent. J Biol Chem 1951;193:265-75.

22. Büyükberber M, Savaş MC, Bağci C, Koruk M, Gülşen MT, Tutar E, et al. The beneficial effect of propolis on ceruleininduced experimental acute pancreatitis in rats. Turk J Gastroenterol 2009;20:122-8.

23. Baxter JN, Jenkins SA, Day DW, Roberts NB, Cowell DC, Mackie CR, et al. Effects of somatostatin and a long-acting somatostatin analogue on the prevention and treatment of experimentally induced acute pancreatitis in the rat. Br J Surg 1985;72:382-5.

24. Cadirci E, Altunkaynak BZ, Halici Z, Odabasoglu F, Uyanik $\mathrm{MH}$, Gundogdu C, et al. Alpha-lipoic acid as a potential target for the treatment of lung injury caused by cecal ligation and puncture-induced sepsis model in rats. Shock 2010;33:479-84.

25. Patel BP, Hamadeh MJ. Nutritional and exercise-based interventions in the treatment of amyotrophic lateral sclerosis. Clin Nutr 2009;28:604-17.

26. Chen XS, Liu H, Ji AM, Yang YL, Yao YF. Effects of sustained release alpha lipoic acid tablet on blood lipid, on blood sugar and insulin in hyperlipidemic New Zeland rabbits. Non Fang Yi Ke Da Xue Xue Boo 2009;29:704-6.

27. Steer ML. Sabiston textbook of surgery. The biological basis of modern surgical practice. 17 th ed., 2007.

28. Steer ML. Relationship between pancreatitis and lung diseases. Respir Physiol 2001;128:13-6.

29. Bhatia M, Brady M, Shokuhi S, Christmas S, Neoptolemos JP, Slavin J. Inflammatory mediators in acute pancreatitis. J Pathol 2000;190:117-25.

30. Gultekin FA, Kerem M, Tatlicioglu E, Aricioglu A, Unsal C, Bukan N. Leptin treatment ameliorates acute lung injury in rats with cerulein-induced acute pancreatitis. World J Gastroenterol 2007;13:2932-8.

31. Eşrefoğlu M, Gül M, Ateş B, Yilmaz I. Ultrastructural clues for the protective effect of ascorbic acid and $\mathrm{N}$-acetylcysteine against oxidative damage on caerulein-induced pancreatitis. Pancreatology 2006;6:477-85.

32. Akyuz C, Sehirli AO, Topaloglu U, Ogunc AV, Cetinel S, Sener G. Protective effects of proanthocyanidin on ceruleininduced acute pancreatic inflammation in rats. Gastroenterology Research 2009;2:20-28. doi:10.4021/gr2009.02.1276.

33. Yamagiwa T, Shimosegawa T, Satoh A, Kimura K, Sakai $\mathrm{Y}$, Masamune A. Inosine alleviates rat caerulein pancreatitis and pancreatitis-associated lung injury. J Gastroenterol 2004;39:41-9.

34. Gül M, Eşrefoğlu M, Oztürk F, Ateş B, Otlu A. The beneficial effects of pentoxifylline on caerulein-induced acute pancreatitis in rats. Dig Dis Sci 2009;54:555-63.

35. Ozkan E, Akyüz C, Sehirli AO, Topaloğlu U, Ercan F, Sener G. Montelukast, a selective cysteinyl leukotriene receptor 1 antagonist, reduces cerulein-induced pancreatic injury in rats. Pancreas 2010;39:1041-6.

36. Magro F, Fraga S, Ribeiro T, Soares-da-Silva P. Regional intestinal adaptations in $\mathrm{Na}+, \mathrm{K}+$-ATPase in experimental colitis and the contrasting effects of interferon-gamma. Acta Physiol Scand 2005;183:191-9. 